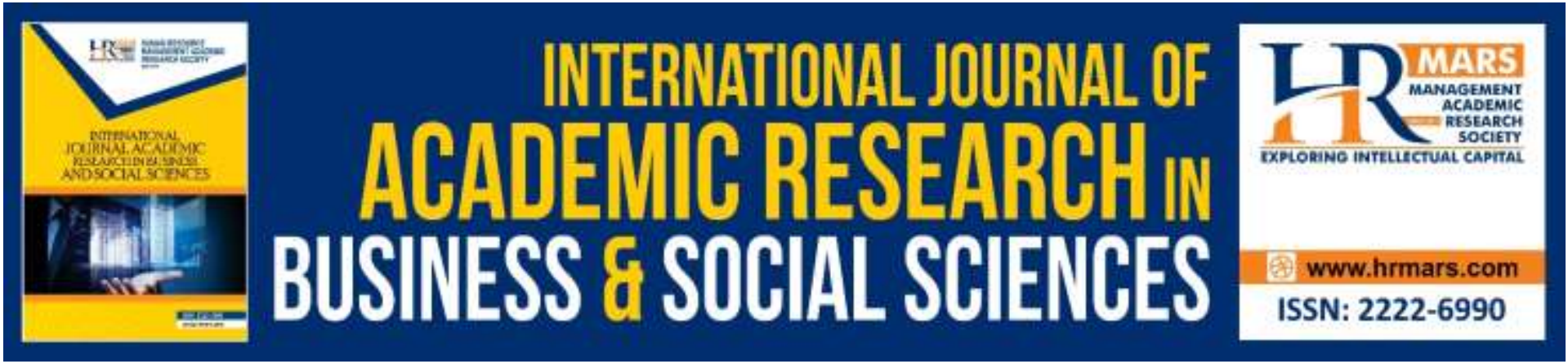

\title{
Malay Historiography based on Traditional History in Building High Order Thinking Skills (HOTS)
}

Ramli Bin Saadon, Baharuddin Bin Jabar, Ahmad Zainuddin Bin Husin, Mohd Kamal Bin Kamaruddin

To Link this Article: http://dx.doi.org/10.6007/IJARBSS/v9-i7/6402

DOI: $10.6007 /$ IJARBSS/v9-i7/6402

Received: 13 May 2019, Revised: 10 June 2019, Accepted: 27 June 2019

Published Online: 23 July 2019

In-Text Citation: (Saadon, Jabar, Husin, \& Kamaruddin, 2019)

To Cite this Article: Saadon, R. bin, Jabar, B. bin, Husin, A. Z. bin, \& Kamaruddin, M. K. bin. (2019). Malay Historiography based on Traditional History in Building High Order Thinking Skills (HOTS). International Journal of Academic Research in Business and Social Sciences, 9(7), 1355-1365.

Copyright: (C) 2019 The Author(s)

Published by Human Resource Management Academic Research Society (www.hrmars.com)

This article is published under the Creative Commons Attribution (CC BY 4.0) license. Anyone may reproduce, distribute, translate and create derivative works of this article (for both commercial and non-commercial purposes), subject to full attribution to the original publication and authors. The full terms of this license may be seen

at: http://creativecommons.org/licences/by/4.0/legalcode

Vol. 9, No. 7, 2019, Pg. 1355 - 1365

http://hrmars.com/index.php/pages/detail/IJARBSS

JOURNAL HOMEPAGE

Full Terms \& Conditions of access and use can be found at http://hrmars.com/index.php/pages/detail/publication-ethics 


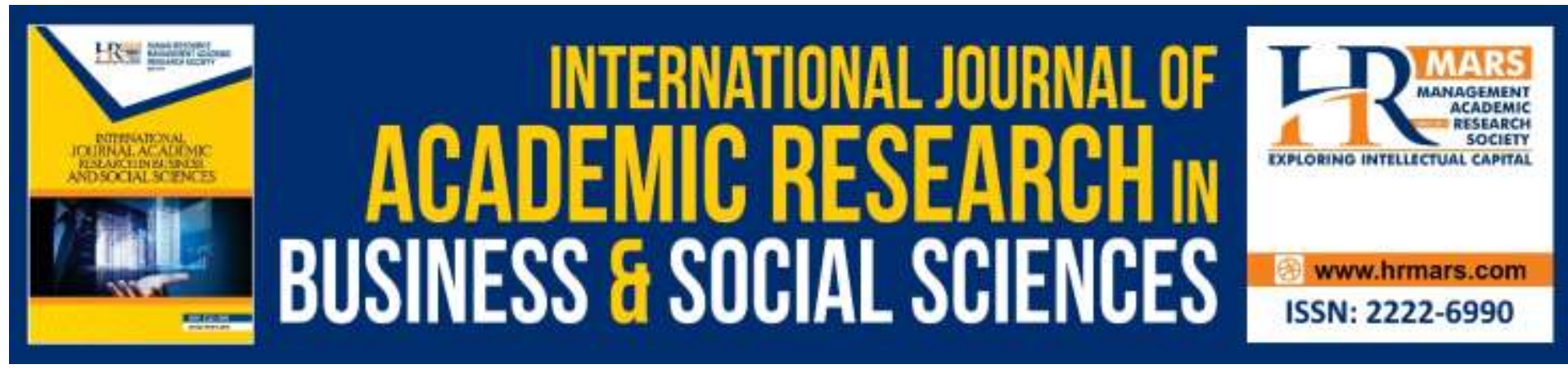

\title{
Malay Historiography based on Traditional History in Building High Order Thinking Skills (HOTS)
}

\author{
Ramli bin Saadon, Baharuddin bin Jabar, Ahmad Zainuddin bin \\ Husin, Mohd Kamal bin kamaruddin \\ Sultan Idris Education University, Tanjung Malim, Perak \\ Email: ramli.saadon@fsk.upsi.edu.my, baharuddin@fsk.upsi.edu.my, \\ zainuddin@fsk.upsi.edu.my, mohdkamal@fsk.upsi.edu.my
}

\begin{abstract}
The historical of curriculum in Malaysia contains various of historical events whether it's related to the things in Malaysia as well as in the world. The historical of curriculum arranged in such way so that all of the students can follow the curriculum throughout the national education system. In 2014, the Ministry of Education Malaysia created history when history subjects were introduced at primary school which started at the second level that is fourth year students by using a curriculum better known as Curriculum Standard Content and Learning (DSKP). Malay historiography is one of the historical events of traditional texts which the way it was written contrasts with the style of modern history writing based on western traditions. Hence, Malay historiography should be an important platform for the sustainability of the Malay tradition history in the context of the Nusantara and Malaya (Malaysia). This study aims to see the ability of students whether in primary or secondary schools using the Malay historiography texts to help their ability to think outside the box based on events or incidents which are written in Malay histriography that are mixed with historical facts, mythical stories and fairy tale. The conclusions from this study are necessary for the efforts of the school and the Ministry of Education to build space for primary and secondary school students in order not to continue making the treasures that contained in Malay historiography be the only study material, it's should be read and appreciated by all students in Malaysia to be aware that the histriography should be the basis to deepen Malaysia's history in a dynamic context.
\end{abstract}

Keywords: Thinking, Histriography, Malay, History

\section{Introduction}

The historical of curriculum in Malaysia contains various historical events whether related to things in Malaysia or in the outside of Malaysia. The historical curriculum is structured like that to enable all students to attend the curriculum throughout the school. In 2014, the Ministry of Education Malaysia created history when the subjects of history were 
introduced at primary school which started at the second level, the fourth year students using a curriculum better known as the Curriculum Standard Content and Learning (DSKP). Malay historiography should be an important platform for the continuity of the Malay tradition history in the context of Nusantara and Malaya (Malaysia). All aspects of historical thinking and statehood are told in the context of works that are not according to the western tradition, especially in modern historical writing. The difficulty of securing historical sources according to the western disciplines causes all the thought in Malay historiography ignored because of the fact that it's does not conform the historical meaning of western thinking. However, without Malay historiography, the various lameness in the minds of the Malays are left behind a history fold.This would undoubtedly harm the historical traditions of the nation and nation. There are many issues in Malaysian History in particular relating to the historical journey of the Malays who have been denied the Malay tradition. This study allows students and teachers studying Malay historiography to enable the thinking of tools to be built to enable teachers and students to apply thinking skills through structured material that has been arranged in the form of themes, political, economic and social. Historical sources written by scholars in the 15th and 18th centuries often use different approaches to western approaches. Hence, through Malay texts and works of histories that have various aspects that can be used as thinking tools need to be applied in every subject of the school. This is in line with the opinion of Marwic (1970) in expressing historical significance to the three concepts that should exist. Hence, through Malay texts and works of histories that have various aspects that can be used as thinking tools need to be applied in every subject of the school. This is in line with the opinion of Marwic (1970) in expressing historical significance to the three concepts that should exist. Those concept, which is in line with the Malay historiography tradition, is a discipline that has been established or at least comparable to philosophy, math, science and other knowledge. Through the provision of modules for the purpose of teaching and learning history, teachers and students apply the predicted histories based on high order thinking skills (HOTS). The important foundation of this study is the existence of a mythical tradition in historical writing which led to the rejection of the sources of Malay historiography. In relation to that, Malay historiography has many important concepts for students in Malaysia who study history through two periods, based on traditional sources and also western sources. Historical writing methods based on Malay historiography do not see the use of authoritative resources. This factor is due to the lack of culture in the Malay World in recording the past history events. In addition, climate conditions in Southeast Asia would not allow historical materials to be stored for a long time because the weather was easily damaged by writers written on animal skins as well as wooden leaves. Hence there existed among the intellectuals who highlighted the writings that could provide a historical picture that at least solved the various historical foundations that need to be explained. 


\section{Definition of Malay Historiographic and High Order Thinking Skills}

The methodology of modern and traditional history of writing has a difference as a result of the 18th century was a source of modern historical writing to prove that event as true. Hence, Malays history in the context of the Malay World is only dependent on historical sources of texts or Great works such as the Malay History. Writing in modern and traditional history disciplines is too different. If Malaysian history only takes a modern context then Malaysia's history will lose its important treasures and heritage. Historical sources of nature with literary texts often include elements of added characters, myths and legends. However, the effort to know the history of colonialism depends largely on the source of historiography.

\section{Research Issues}

High Level Thinking Skills (KBAT) is needed in helping to advancing the political, economic and social development of the community. The development of thinking situation which is based on lateral thinking wants all aspects of life to be tackled in the face of a new variety situations that are more challenging. The human mind needs certain tools to enable the thinking process to occur. In Malay historiography is often criticized for historical elements mixed with myths and regarded as groundless in real world. This led to scholarly circles who were involved with historical discipline regarded that side aspect as something that could confuse facts or historical events.

However, the new developments have shown that the Malay historiography tradition requires the power of creativity and critical thinking to enable teaching and learning to occur. The idea of historical thinking needs to be refined with thinking ability especially to make interpretation based on writing in Malay historiography full of facts, philosophy, myths, legends and etc. If every age has the same traditions, the aspect of advantage does not exist in every age. This study attempts to state that the thinking of society at all times is manifested by various methods and requires certain skills to understand the philosophy, thinking and ethos of society. The study only saw that Malay historiography is not acceptable as a source of history is not fair and weak. Therefore, this study attempts to present a new discovery that the historical aspect of mixed myths and legends is actually an important aspect to the community development in its time. Making a court of a historical tradition based on Malay historiography as a disability is a court of view without regard to every age that has the goal and philosophy in ensuring that peoples will come to think about the lessons of the historical events. Therefore, this study focuses on the Malay historiography to be examined as an indispensable aspect of education that is the High Order Thinking Skills (HOTS) that will drive the development of society in the future. Through the Malay historiography the thinking tool becomes an important aspect in cognitive constructs in historical thinking based on interpretation, analysis, evaluation, inference, explanation and self-confidence building. Therefore, it is clear that Malay historiography has various concepts that can be used as a tools of thinking in developing society in the fields of economy, politics and social. This finding will be able to propel high order thinking skills that are very important in teaching history at the primary and secondary schools. Adam (2016) in his book Antara Sejarah dan Mitos, Sejarah Melayu \& Hang Tuah in Malaysia Historiography only emphasizes the pursuit of truth in history and places many aspects in Malay histories as less useful. However, the aspect of Malay historiography is not only seen from the historical truth point of view but must be seen in the context of philosophy of historical thinking as a high order thinking in learning history lessons either in the primary or secondary level. 


\section{Research Methodology}

In order to provide a Malay Historiography module as a tool of thinking in HOTS, the methods used are qualitative and quantitative methods (Mixed Method). Qualitative methods require all content in Malay historiography to be examined to enable the important themes based on economic, political and social can developed to enable the creation of HOTS tools embodied. Hence, all aspects of manuscripts or those that have been maintained are restructured to be able to build important themes to enable all aspects of history to be studied without regard to the truth of the myth or the legend. There are various sources in Malay historiography that can clarify the journey history in Malaysia, especially in the 15th to the 18th century. Nevertheless, often the historical writing method of the century has been criticized for the myths and fairy tales that were included in a narrative in the history of events. Once all the materials related to the Malay historiography are collected, the material will be classed as a means of thinking in generating high order thinking in historical teaching. The quantitative method that involves randomly build to enable the module to be tested and also made a pilot study to allow aspects involving creative and critical thinking to be generated based on historical sources in Malay historiography. Important themes are built on political, economic and social events. On the basis of random sampling towards the selected schools, all the procedures for using the model are derived from the source of Malay historiography to see the high level thinking skills that can be generated through certain stages, especially the taxonomies that should be achieved by the student at the required level.

i. Examining all sources that can be classified as Malay historiography that can illuminate a historical event. The source of the historiography is either in the form of manuscripts and also that have been maintained.

ii. The sources are compiled in the form of manuscripts, poems, pantun, storytelling, couplets and so on. What's important is that the content touches historical events especially in the 15th to the 18th century.

iii. All the stories related to the history of the Malay World will be classified in the political, economic and social themes.

Based on all materials that have been collected and made welding based on political, economic and social themes. The materials will be compiled to enable teachers and students to utilize Malay histories to enable students and teachers to generate historical thinking based on Malay historiography. 


\section{Analysis Data and Discussion}

The findings of the test based on the tests given to secondary and lower secondary students found that Malay historiography materials were poorly exposed in schools due to the difficulty of providing materials suitable to the students' level. In the historical subject, teachers did not disclose to their pupils the Malay historical historiography material that related to historical events. However, the findings show that the use of Malay historiography material has attracted the students to see the various aspects of history written in the way of traditional Malay history writing. Thinking skills can be generated through student endeavors to look at various historical events written by adding various ideas that are classified as myths, legends and fairy tales. When students are given a series of events quoted from the Malay historiography material, students have sought to organize various aspects that can be classified as historical sources of history. The researcher has disseminated various questions based on Malay historiography source and presented a thinking chart based on Anderson's Taxonomy and Krathwohl (2001). In this study, the most important is the arrangement of the taxonomies for the historical subjek that is quite different from the other subjects. The subject of history is a subject that tells the past.

Therefore, the aspects of knowledge, understanding and application of historical events can be compiled based on facts found. Hence, students who are able to achieve the taxonomy level are trying to boost the ability to use historical facts to achieve a higher level. In this study, two materials of Malay historiography are quoted from the Malay history book of Shellabear (1973). The researcher rearrange the story to make some changes to the use of classical Malay language.

Analysis on Thinking Skills based on the source of Malay historiography.

1. Royal System

2. Leadership Magnifier

3. Status and Ranks

4. Malay Community Tradition

5. The View of The Royal System

6. Criticism of the Malay Traditional Society System

Malay history can not be classified as a source of history in the context of writing modern history. However, in Malaysia, before the British influence, historical sources are not seen as factual facts based on written or recorded documents only to be classified as a natural source.

In the 15th century until the early 18th century, historical sources based on Malay historiography were very important. This is because of the Malay community who wrote history in the context of classical tradition did not prove that the event was based on documents or written sources but had historical elements that could be classified as fact. With that, the source of its nature as history is characterized by the figure and the mythical aspects and the legend. It is a disadvantage if students at school are not exposed to the sources of Malay historiography and may have bad implications for the breakdown of historical chronology and may affect the historical significance itself. It does not matter whether the source is dealing with a variety of criticisms, but what is important is historical facts that can make history known. What matters is history is the truth, but the method of writing requires 
every generation of minds to look at the historical sources scientifically and not teasingly reject the source as the excuse of the change of historical concept.

\section{Royal System}

Respondents were given a passage that could explain the beginning of the existence of the Malay Kings in Malaysia until now. Before the students answered the question, students were brought to talk about the existence of Malay rulers at this time. Therefore what is important is the beginning of the history of the Malay rulers. Thinking skills that should be study is the ability of the pupil to explain the advantages of the king's system to becoming a practice in Malaysia. Therefore an important aspect is the reason given in looking at the history of the Malay rulers in Malaysia.

Passage 1

Startly, told by someone of the story owner, as for Palembang that exist now; was a big city a long time ago, and that the King of Palembang' names Demang Lebar Daun, have giving birth to a good-looking girl, no one can defeat her beautifulness that time, her name is Wan Sedari. Then presented by Wan Empuk and Wan Malini towards Sang Sapurba that Demang Lebar Daun has a daughter; then he ordered to proposed. Demang Lebar Daun then presented, "If you married my daughter, trust me she'll be a luminous; but if you want to make an agreement with me, then I'll presented my daughter to you, Your Majesty."

As for words ' $I$ ' (in Malay royal speech) and 'Your Majesty' is firstly introduced by Demang Lebar Daun.

Then Sang Purba order, "What is that my father wants?"

Then Demang Lebar Daun said "As for all my grancdchildren will be ready to be your servant, Your Majesty; had to be repaired by your grandchildren, Your Majesty. And if it's sin, as its' great sin, don't diffused, disgrace with despicable words. If the great sin is killed, if it's happen to islamic low."

Then Sang Purba order" About your father's want you can give it, but I asked for a promise to your father."

Then Demang Lebar Daun asked "Which promise is that, Your Majesty?" Sang Purba then answered "At the end of time your parents' grandchildren should not rebel against our offspring, if they are cruel and even evil in character."

Then Demang Lebar Daun said "As you ordered, Your Majesty. But if your grandchildren changes it, then my grandchildrem need to changes it too."

Then ordered Sang Sapurba, "All right, your demand will be fullfilled."

(Quoted by Sejarah Melayu Shellabear 1973 edition)

Based on the respondents' responses, it is clear that almost 80 percent of the students can not compile the formulas that can be classified as a fact to explain why the Malay rulers have the advantage.For20 percent of respondents just put the king as powerful, so things that are the advantages of the king are less criticized whether the matter is logical or otherwise. Research finding the answer to the question that is ; 
- Discussing the traditional textual works that can provide historical facts.

Response from the Students of Primary and Secondary towards the King System in Malaysia

Before the respondents answered, the researchers had told the story of the Malay rulers based on historical facts that was written in modern sources and also based on Malay history. It turns out that the respondents are excited to know the historical sources based on the great works whose writing does not follow modern history. Respondents are generally inferior to historical sources based on historiography.

Thus there are respondents who criticize the way of honor to the king who is considered to be excessive. Based on the students' point of view following the source of historiography that led to the existence of a king system in Malaysia, most respondents says that there is good value in the king. In order to generate a thinking skills, historical concepts are not achieved through teaching in secondary and primary schools. Based on the respondents who are still in form four, respondents can not distinguish the concept of old kings with the present. They just say the king had a lot of power compared to nowadays. Therefore, the application of application-based thinking skills in particular the introduction of British administration can not be understood by students. Therefore the ability to give reason or the interpretation given is weak. The factor is because they lack in the facts of a historical event. Hence, the ability to master the facts thoroughly is that the ability of a student to build or perform interpretation can be done. The percentage of students who did not know the history of the Malay rulers was high that is almost eighty percent. Based on the instrument given to the respondents of forty students, almost half can not explain the history of the Malay rulers. Thus, there is a lack of history in the subject because it is unable to use a source of historiography to allow students to think in explaining historical events. Obviously the chronological aspects as expected in the History Thought Skills, which are the building of skills in the chronology of a difficult event.

\section{The Royalty of King in Malaysia}

Based on the students' responses to the king in Malaysia, it is clear that almost ninety percent of students can not explain the role of the king from traditional to modern. Among the students can only say that the role of the king in the past was vast and present only in terms of religion. Nearly ninety percent can not raise any grounds for the change of power. Hence the historical aspect studied at the school level can not be applied to see the current royal system.

\section{Status Ranks}

The aspect of the relationship between the king and the people recorded as an agreement between the king and the people as recorded in the Malay Version (Shellabear 1975 edition) can not be interpreted by respondents among students. This means that the use or application of historical facts based on modern historical methods is so limited that amongst the students can not see why people are so obedient to the king over existing advantages or otherwise. The decline of the king's descendants in Palembang has changed this environment. This can not be stated by the students about the advantages of the king so that the people continue to be loyal to the king. Through written history based on written documents it has become an essential foundation for students to study history in secondary 
and low schools. Therefore, there is a disunity as it is evident that students studying history can not use historical facts of myths and legends. Hence, among the history teachers can use historiography material so students can comment on the source of Malay historiography to enable the student's ability to be improved.

Passage 2

Said by Sahibul Hikayat that's Sultan Mansor Syah' sons, Raja Ahmad and Raja Muhammad, both are grown up and become adult. Sultan Mansor Syah wish Raja Muhammad will be his substitute because his dearest towards Raja Muhammad.

Once upon a time, Raja Muhammad goes to playing horses riding in Kampong Bendahara Padauka Raja. A son of Bendahara, Tun Besar that time is playing Sepak Raga at the road with all young men. Then Raja Muhammad pass throught while Tun Besar kick the ball. Then the ball fall over Raja Muhammad' destar, fall to the ground. Then Raja Muhammad said "Geez! Our destar falled down because Tun Besar." while staring to his crew.

Then Raja Muhammad stabbed him up through the heart. Tun Bear then die. Peoples saw the death of Tun Besar, it then uproaring all the Bendahara Paduka Raja' crews, all of them come out with all their weapons tools might. Then Bendahara Paduka Raja come out asking "what's the reason behind this peoples uproaring?"

Then said by the people, "Your son, Tun Besar is die killed by Raja Muhammad."

Then the peoples continues told the whole story to Bendahara Paduka Raja. Then Bendahara said, "if it's so, why do you all gather like this?

Then all of the Bendahara's crews replied, "they should all seek revenge on the death of all my relatives."

Bendahara then said "Hey! Hey! Are all you want to rebellious? Do you all disobeyed? Geez! All of you. Geez! because there is no custom, the Malay servant has never been rebellious. But don't let us worship this King's son.

From this passage, the respondents in the context of high order thinking can present aspects of analysis and assessment. The important aspect posed by the response was the aspect of justice. Almost ninety percent of respondents put the King of Muhammad being unfair for killing Tun Perak. Clearly here the quotation of this Malay historiography has attracted the respondents to criticize the king for not putting the aspect of justice.

- Analyze the method of writing history in the Malay histories text as an effort to build high order thinking skills.

From the two passages of Malay histories of the source given to the respondents, it is found that it can help the students to strengthen their understanding of the truth based on the sources of western or modern history. Indeed there is a view that history is the truth, but in the context of Malay historiography various aspects are mixed up to explain a historical event. The important is there historical facts, but the fact that without a description or interpretation does not make history meaningful and fun to learn. An important aspect based 
on the Malay historiographical text that relates to the basic principles of the Malay rulers is the existence of an agreement or agreement which should be an important philosophy in the monarchy system practiced in Malaysia. If viewing the writing method of the Malay rulers, it is clear that the author has put forward various aspects to enable something that has taken into account the various procedures to avoid the disadvantages. So the authors have come up with various ideas and insights to enable generations to come to be in a constant state of thinking in making a decision.

\section{Conclusion}

The conclusions from this study are the need for teachers to use Malay historiography materials to help students achieve the historical Drawing Skills which involve five important points is understand the chronology, exploring evidence, interpreting, making imperative and making rationalization will not be achieved if teachers are not willing to use historiography sources due to the early history of Malaysia relying heavily on modern sources. Historiography sources that are not only historical but rather texts that include elements of myth and legend. The advantages of Malay historiography, especially history-based work if used well will be easier to guide students for them to move to a level of thought that is a passion for the Malaysian Education Blueprint 2013-2025.

\section{Acknowledgement}

This article was a result of University Research Grant (GPU) funded by Universiti Pendidikan Sultan Idris. Research under the supervision of Research, Management and Innovation Centre (RMIC) Universiti Pendidikan Sultan Idris. Research code: 2017-0174-107-01

\section{References}

Rashid, A. R. A. (1998). Ilmu Sejarah: Teori dan Amalan dalam Pengajaran dan Pembelajaran Sejarah,Kertas Kerja Sempena Simposium Kebangsaan IImu Sejarah (1998), Jabatan Sejarah, Universiti Malaya, Kuala Lumpur

Abdullah, A. R. (1994). Pengantar Ilmu Sejarah, Pusat Pengkajian Luar Kampus, Dewan Bahasa Pustaka

Sham, A. H. (1995). Syair-syair Melayu Riau,Kuala Lumpur, Perpustakaan Negara Malaysia

Adam, A. (2014). Antara Sejarah dan Mitos, Sejarah Melayu \& Hang Tuah dalam Historiografi Malaysia, Petaling Jaya, Malaysia, SIRD

Elias, A. (1995). Objektiviti dan Pensejarahan, Forum Serantau, International Islamic of Thought and Civilization.

Noor, A. M. (2006). Ilmu Sejarah dan Pensejarahan, Kuala Lumpur, Dewan Bahasa Pustaka

Booth (2003), A teaching History at University: Enhancing Learning and Understanding, London.

Burnnham, S., and Brown, G. (2008). Assessment without Level Description, Teaching History. Andaya, B. W, and Matheson, V. (1995). Islamic Thought and Malay Tradition, The Writting of Raja Ali Haji of Riau

Breisach, E., Histriography (1983): Ancient Medieval \& Modern, Chicago, The University of Chicago Press

Calderhead, J. (1984). Teacher Classroom Decision Making, Eastbourne

Carr, E. H. (1984). Apakah Sejarah? Terjemahan Muhd Yusof Ibrahim, Kuala Lumpur, Dewan Bahasa dan Pustaka 
Collingwood, R. G. (1994). The Idea of History, Oxford, London, Oxford University Press Cunningham, R. (2000). Teaching Pupil how History Works. Teaching History, London Ian Phillips, (2008). Teaching History, Developing as a Reflective Secondary Teacher, Sage, London

Edwards, C. (2006). Putting Life into History: How Pupil can Use Oral History to Become Critical Historian

Mills, L.A., British Malaya, 1842-1867 (1960), Journal of the Malayan Branch of the Royal Asiatic Society, Kuala Lumpur.

Maxwell, W., E (1882).,The History of Perak from Native Sources, Journal of the Straits Branch of the Royal Asiatic Society, Vol. IX, no.9

Lanham, Lexinton Books 